Available online at HISTORIA; Jurnal Pendidik dan Peneliti Sejarah
Jurnal homepage: https://ejournal.upi.edu/index.php/historia

\title{
PENGEMBANGAN MEDIA PEMBELAJARAN AUDIO BERBASIS PODCAST PADA MATERI SEJARAH LOKAL DI SUMATERA SELATAN
}

\author{
Adhitya Rol Asmi, Aulia Novemy Dhita, Supriyanto \\ Departemen Pendidikan Sejarah, FKIP, Universitas Sriwijaya \\ adhityarolasmi@unsri.ac.id
}

$\overline{\text { To cite this article: Asmi, A.R., Dhita, A.N., Supriyanto. (2019). Pengembangan media pembelajaran audio berbasis podcast }}$ pada materi sejarah lokal di Sumatera Selatan. HISTORIA: Jurnal Pendidik dan Peneliti Sejarah, 3(1), 49-56. https://doi. org/10.17509/historia.v3i1.21017.

Naskah diterima : 12 November 2019, Naskah direvisi : 26 November 2019, Naskah disetujui : 30 Desember 2019

\begin{abstract}
This study contains data on local history, Sriwijaya. The formulation of the problem of this research is how the Media physical Model of the learning based Audio Podcast on the subjects of ancient Indonesian history and how effective Mediabased learning Audio Podcast on the subjects of ancient Indonesian history. As for the purpose in this research is to get the prototype Media based Audio Podcast in the course of ancient Indonesian history and know the effectiveness of Media-based learning Audio Podcast on the course of history Ancient Indonesia. This research is a development study using the ADDIE research model. The development steps of the ADDIE model are as follows (1) analysis, (2) Design (3) Development (4) Implementation (5) evaluation. This learning media is judged by three expert teams, namely material experts, linguists and media experts. Eligibility material has a value of 4.78 with valid categories, validity and language of 4.38 with valid categories, and validity of the media with a value of 4 with a valid category. This development research has been conducted and applied to the students of the history of Sriwijaya University on the subject of ancient Indonesian history. The potential effect of the use of Audio-based media Podcasts in the field trials stage with the average result of Pretests is 36.42 with very low category and then average postest ie 82.32 with good category. There was an increase of $45.9 \%$ and a value of $\mathrm{N}$-gain 0.72 if $0.72 \geq 0.7$ then included in the High category. This shows that Audio-based media Podcast on Sriwijaya material has been successfully applied and has a value of validity and has an effective impact.
\end{abstract}

Keywords: Audio; ADDIE; Learning Media; Podcast.

\begin{abstract}
Abstrak
Penelitian ini memuat data mengenai sejarah lokal Sriwijaya. Rumusan masalah penelitian ini adalah bagaimana Model Fisikal Media pembelajaran berbasis Audio Podcast pada mata kuliah Sejarah Indonesia Kuno dan bagaimana efektifitasnya. Adapun yang menjadi tujuan dalam penelitian ini adalah mendapatkan prototype Media pembelajaran berbasis Audio Podcast pada mata kuliah Sejarah Indonesia Kuno dan mengetahui efektifitasnya. Penelitian ini merupakan penelitian pengembangan yang menggunakan model penelitian ADDIE. Langkah-langkah pengembangan model ADDIE adalah sebagai berikut (1) Analisis, (2) Desain (3) Development (4) Implementasi (5) Evaluasi. Kevalidan media pembelajaran ini dinilai oleh empat tim ahli, yaitu ahli materi, ahli bahasa, dan ahli media. Kevalidan materi memiliki nilai sebesar 4,78 dengan kategori valid, kevalidan bahasa sebesar 4,38 dengan kategori valid, kevalidan media dengan nilai sebesar 4 dengan kategori valid dan kevlidan desain pembelajaran dengan kategori sangat valid. Penelitian pengembangan ini telah dilakukan dan diterapkan pada mahasiswa Pendidikan Sejarah Universitas Sriwijaya pada mata kuliah Sejarah Indonesia Kuno 1. Efek potensial penggunaan media Audio berbasis Podcast pada tahap Uji coba lapangan dengan hasil rata-rata pretest yaitu 36,42 dengan kategori sangat rendah dan kemudian rata-rata postest yaitu 82.32 dengan kategori baik. Terjadi peningkatan sebesar $45,9 \%$ dan nilai $\mathrm{N}$-gain 0,72 jika $0,72 \geq 0,7$ maka termasuk dalam kategori tinggi. Hal ini menunjukan media Audio berbasis Podcast pada materi Sriwijaya telah berhasil diterapkan dan memiliki nilai kevalidan dan memiliki dampak efektifitas.
\end{abstract}

Kata Kunci: ADDIE; Audio; Media Pembelajaran; Podcast.

HISTORIA: Jurnal Pendidik dan Peneliti Sejarah, p-issn:2620-4789 | e-issn:2615-7993 


\section{PENDAHULUAN}

Pendidikan menjadi sebuah proses belajar yang didalamnya terdapat jaringan informasi dari pendidik kepada peserta didik dan sebaliknya dari peserta didik kepada pendidik. Proses informasi tersebut akan membentuk sebuah interaksi yang aktif sehingga dapat meningkatkan cara berpikir, mengubah pola perilaku menjadi baik. Perkembangan teknologi yang semakin canggih sekarang dan disebut sebagai bagian dari revolusi industri 4.0, telah membuat proses pembelajaran tidak harus bertatap muka (face to face) di dalam kelas. Mahasiswa bisa melakukan banyak kegiatan dalam satu waktu (multitasking), sehingga dalam hal ini dibutuhkan sebuah media pembelajaran berbasis Audio Podcast.

W.S. Winkel mengatakan media pembelajaran dapat diterjemahkan secara meluas dan sempit: pertama, secara luas, media merupakan beberapa individu, materi atau kejadian yang memberi jalan ke peserta didik untuk memperoleh ilmu, keahlian dan kepribadian. Kedua, secara sempit, media merupakan alat-alat yang menjadi jembatan antara peserta didik dan materi pembelajaran, contohnya laptop dan televisi (Susanto, 2013).

Peneliti akan mengembangkan media pembelajaran berbasis Audio Podcast dimana Podcast merupakan sebuah media yang bisa digunakan dengan cara mendengar Audio melalui komputer, laptop, HP android. Media Audio Podcast ini bisa merekam suara yang dibuat dengan skenario yang bisa membuat pendengarnya merasa terbawa keadaan yang sebenarnya. Podcast diartikan sebagai materi Audio atau video yang tersedia di internet yang dapat secara otomatis dipindahkan ke komputer atau media pemutar portable baik secara gratis maupun berlangganan (Fadilah, Yudhapramesti, dan Aristi. 2017).

Teknologi informasi memiliki peran terciptanya, interaksi antara dosen dan peserta didik (mahasiswa) bukanlah sebuah halangan yang berarti lagi. Saat ini teknologi melalui media telah menjadi solusi pembelajaran yang dapat dilakukan dimana pun dan kapan pun. Teknologi media memberikan ruang bagi dosen untuk memberikan informasi dalam bentuk file (dokumen, Audio, video), melalukan interaksi melalui chat, dan melalakukan evaluasi melalui media.

Interaksi antara dosen dan mahasiswa dalam memahami sebuah materi bisa difasilitasi dengan media pembelajaran. Media pembelajaran merupakan sebuah alat yang bisa digunakan sebagai perantara dalam sebuah proses pembelajaran agar pembelajaran tersebut bisa dengan mudah tersampaikan. Dosen sebagai seorang pengajar tidak bisa hanya dengan menggunakan metode ceramah saja tanpa menggunakan media pembelajaran.
Rencana penelitian ini juga sesuai dengan sasaran, Rencana Induk Pengembangan Penelitian Universitas Sriwijaya tahun 2016-2020 dengan program strategis dan indikator kinerja bidang penelitian media pembelajaran dan ICT pada program riset pendidikan sejarah yaitu meningkatkan hasil media pembelajaran berbasis ICT yang berisi materi pembelajaran yang sesuai dengan kurikulum yang digunakan pada program studi pendidikan sejarah. Penulis akan mengembangkan media pembelajaran Audio berbasis Podcast materi Sejarah Lokal di Sumatera Selatan. Materi ini memiliki konten yang menarik dan sangat panjang sehingga pengemasan materinya bisa lebih efektif apabila menggunakan media pembelajaran Audio berbasis Podcast.

Penelitian ini lebih mengkaji tentang pengembangan media pembelajaran berbasis audio podcast untuk mata kuliah Sejarah Indonesia kuno. Dimana penelitian ini bersifat pengembangan dalam ilmu pendidikan yang menjadi skemanya untuk mendapatkan materi yang dikemas secara audio podcast. Berdasarkan latar belakang yang dikemukakan di atas maka yang menjadi permasalahan dalam penelitian ini adalah: (1) Bagaimana Model Fisikal Media pembelajaran berbasis Audio Podcast pada mata kuliah sejarah indonesia kuno? (2) Bagaimana efektifitas Media pembelajaran berbasis Audio Podcast pada mata kuliah Sejarah Indonesia Kuno?.

Penelitian yang menggunakan media pembelajaran berbasis podcast merupakan sebuah penelitian yang sudah pernah dilakukan sebelumnya. Andi wicaksono meneliti peran media Audio dalam meningkatkan kualitas proses pembelajaran apresiasi cerita pendek. Hasil penelitiannya menunjukan bahwa tujuan pembelajaran bisa tercapai secara optimal dengan perekaman suara untuk cerita pendek yang berindikasi terhadap meningkatnya keaktifan dan keberanian siswa dalam proses pembelajaran (Wicaksono 2017).

Selain itu, Ratminingsih meneliti efektifitas media Audio pembelajaran bahasa inggris berbasis lagu kreasi dikelas 5 sekolah dasar. Ratminingsih menyatakan bahwa media Audio behasil meningkatkan hasil belajar siswa karena pembelajaran menjadi menyenangkan, menarik dan mudah dipahami sehingga menimbulkan respon positif terhadap pemnfaatan media Audio ini (Ratminingsih, 2016).

Sedangkan penelitian yang dilakukan oleh Rieka Mustika yang mengkaji media pembelajaran sistem Audio untuk pemberdayaan pendidikan dikomunitas masyarakat. Penelitian ini mencoba untuk mengemas sebuah materi dengan menggunakan komputer dengan nama CAI (Computer Assited Instruction) dengan sistem perekaman digital sehingga dapat menunjang 
HISTORIA: Jurnal Pendidik dan Peneliti Sejarah, 3(1), 49-56. DOI: https://doi.org/10.17509/historia.v3i1.21017.

pembelajaran untuk mencapai tujuan pembelajaran (Mustika, 2015).

Hasil penelitian diatas menunjukan bahwa lebih kepada perekaman materi yang diperuntukan keaktifan belajar siswa dalam mencapai tujuan pembelajaran tanpa melakukan rekonstruksi bahan ajarnya, sedangkan penelitian yang dilakukan oleh peneliti akan mengembangkan media pembelajaran Audio berbasis Podcast dengan merekonstruksi materi Sejarah Lokal di Sumatera Selatan untuk mata kuliah Sejarah Indonesia kuno. Materi ini memiliki konten yang menarik dan sangat panjang sehingga pengemasan materinya bisa lebih efektif apabila menggunakan media pemberlajaran Audio berbasis Podcast.

Berdasarkan latar belakang masalah yang dikemukakan di atas maka dapat dirumuskan tujuan penelitian pengembangan ini adalah Tujuan penelitian ini adalah untuk (1) Untuk mendapatkan prototype Media pembelajaran berbasis Audio Podcast pada mata kuliah Sejarah Indonesia Kuno (2) Untuk mengetahui efektifitas Media pembelajaran berbasis Audio Podcast pada mata kuliah Sejarah Indonesia Kuno.

\section{METODE PENELITIAN}

Studi Pendahuluan bertujuan untuk memperoleh data secara komprehensif tentang kebutuhan media pembelajaran yang ada di Progam Studi Pendidikan Sejarah FKIP Unsri. Pada tahap selanjutnya, peneliti melakukan kajian terhadap produk serupa yang sudah pernah dikembangkan sebelumnya oleh peneliti lain. Tujuannya adalah untuk menguji dan membandingkan efektifitas fitur-fitur yang ada pada media-media tersebut agar dapat diterapkan pada media yang akan dikembangkan. Data-data seperti penelitian-penelitian terdahulu seperti rujukan penelitian-penelitan sejenis yang tercantum di jurnal-jurnal nasional dan internasional yang sesuai dengan produk yang akan dikembangkan.

Pada penelitian yang dilakukan oleh Andi wicaksono dengan judul peran media Audio dalam meningkatkan kualitas proses pembelajaran apresiasi cerita pendek mengatakan bahwa tujuan pembelajaran bisa tercapai secara optimal dengan perekaman suara untuk cerita pendek yang berindikasi terhadap meningkatnya keaktifan dan keberanian siswa dalam proses pembelajaran (Wicaksono 2017). Selain itu, penelitian yang dilakukan oleh Ratminingsih dengan judul efektifitas media Audio pembelajaran bahasa inggris berbasis lagu kreasi dikelas 5 sekolah dasar menyatakan bahwa media Audio berhasil meningkatkan hasil belajar siswa karena pembelajaran menjadi menyenangkan, menarik dan mudah dipahami sehingga menimbulkan respon positif terhadap pemnfaatan media Audio ini (Ratminingsih, 2016).

Sedangkan penelitian yang dilakukan oleh Rieka Mustika yang berjudul media pembelajaran sistem Audio untuk pemberdayaan pendidikan dikomunitas masyarakat. Penelitian ini mencoba untuk mengemas sebuah materi dengan menggunakan komputer dengan nama CAI (Computer Assited Instruction) dengan sistem perekaman digital sehingga dapat menunjang pembelajaran untuk mencapai tujuan pembelajaran (Mustika, 2015).

Peneliti juga melakukan observasi pra penelitian terhadap tempat pembuatan media pembelajaran Audio berbasis Podcast dan tenaga ahlinya. Setelah datadata terkumpul maka bisa dijadikan sebagai landasan atau bahan pertimbangan dalam Pengembangan media pembelajaran Audio berbasis Podcast, sehingga diharapkan akan memperoleh produk yang tepat sasaran sesuai dengan kebutuhan dan kemudian tujuan dari pengembangan produk pembelajaran ini bisa tercapai.

Penelitian pengembangan tentunya harus melalui prosedur tertentu, diaman dalam penelitian ini menggunakan Model ADDIE. Model ADDIE merupakan model yang digunakan untuk menghasilkan produk pembelajaran yang efektif dan efesien yaitu Audio berbasis Podcast, pada proses pembelajaran yang menggunakan media dan teknologi. ADDIE adalah model desain instruksional yang berlaku untuk semua jenis pendidikan dan terlepas dari kenyataanbahwa ADDIE terdiri dari komponen dari semua model desain lain, itu adalah model yang relatif sederhana. Kata ADDIE adalah akronim dari huruf kapital dari katakata: analisis, desain, pengembangan, implementasikan, dan Evaluasi (Arkün dan Akkoyunlu, 2008).

Penelitian dan disesuaikan dengan produk yang akan dikembangakan yaitu media pembelajaran audio berbasis podcast materi sejarah lokal Sumatera Selatan, setelah disederhanakan atau disesuaikan berikut adalah tahapan-tahapan dalam implementasinya, yang terdiri dari lima langkah. Pertama, tahap analisis. Langkah ini adalah proses deskripsi dari apa yang akan diajarkan dan langkah awal dari pembentukan langkah selanjutnya Pada langkah ini, peneliti menentukan kebutuhan peserta didik dalam hal pengetahuan, keterampilan dan perilaku, yang saat ini dimiliki oleh peserta didik, serta hasil yang akan diharapkan dari peserta didik tersebut (Branch, 2009).

Kedua, Tahap Desain dari model pengembangan ADDIE, dimana tahap ini merupakan proses penentuan bagaimana proses yang telah didapat dari tahap analisis untuk dipelajari lebih lanjut. Dalam langkah ini, 
strategi pengembangan ditentukan sesuai dengan data yang diperoleh selama analisis. Pada fase ini peneliti akan menentukan tujuan akan dicapai pada proses pembelajaran dengan menentukan desain instruksional pembelajaran, instrumen yang digunakan untuk pengumpulan data analisis kebutuhann yaitu angket yang berisikan butir-butir pertanyaan yang sesuai dengan kebutuhan.

Ketiga, tahap Pengembangan. Pada tahap ini peneliti akan mengolah semua komponen yang berhubungan dengan Audio yang akan diolah melalui Podcast dan disiapkan selama fase ini. Tahap ini merupakan proses memproduksi bahan instruksi berupa pengelolaan materi dan media Audio, Penyusunan naskah semua alat yang akan digunakan selama instruksi dan segala jenis bahan pendukung. Semua produk dibuat pada tahapan ini tidak hanya Audio yang diolah di Podcast namun juga Instrumen angket, soal dan alat penilaian evaluasi yang akan digunakan peneliti. Pada tahap ini juga peneliti melakukan Validasi dengan 3 Ahli yaitu ahli Materi, Ahli Desain pembelajaran dan Ahli Media, ketika ahli tersebut akan menentukan sudah layak atau belum media yang akan diuji cobakan kepada peserta didik.

Langkah ini menjadi penentu keberhasilan pada langkah selanjutnya sehingga tahap ini peneliti benar-benar merencanakan semua secara terperinci sebelum Prototype diuji cobakan dan semua komponen lingkungan belajar dikembangkan dan lingkungan dipersiapkan untuk ujian. Pada tahap ini data-data yang dikumpulkan untuk kebutuhan media dikelola menggunakan aplikasi Podcast untuk menghasilkan media Audio dan peneliti melakukan validasi dengan tiga ahli untuk menguji kelayakan media yang akan digunakan dalam pembelajaran dengan alat ukur yaitu berupa angket atau kuesioner, setelah itu peneliti akan melakukan evaluasi dan mengetahui kelayakan media sebelum langkah selanjutnya.

Keempat, tahap implementasi Ini adalah proses penentuan instruksi yang memadai dan mengukur efektivitas dalam untuk memeriksa sejauh mana desain pembelajaran serta media Audio Podcast yang telah diuji cobakan pada peserta didik. Pada tahap evaluasi ini peneliti menggunakan evaluasi formatif dimana evaluasi formatif memiliki empat tahapan yang berupa, Ahli review atau validasi tiga ahli yang telah dilakukan pada tahapan sebelumnya yaitu tahapan pengembangan, dikarenakan evaluasi secara langsung terkait dengan semua empat tahap sebelumnya, mungkin perlu kembali ke salah satu dari tahapan sebelumnya pada akhir fase ini.

Kelima, tahap evaluasi yaitu melaksanakan One to One Learner dengan membentuk grup belajar satu satu dan melaksanakan penilaian tahap dua melalui angket kemudian merevisi apa yang kurang, peneliti melakukan tahapan evaluasi kedua yaitu melakukan Small Group yaitu membentuk grup belajar kecil untuk merevisi media yang digunakan dan melaksanakan penilaian tahap ketiga melalui angket serta melakukan revisi jika ada yang kurang pada media, kemudian tahapan selanjutnya, yaitu Fieldtest yang merupakan tahapan Uji coba yang berkaitan dengan tahapan ADDIE pada tahap implementasi sebelum melakukan tahapan Implementasi peneliti akan melakukan Pretest dan setelahnya peneliti akan melakukan Postest untuk menentukan efektivitas media yang digunakan. Bagian akhir masing-masing tahapan evaluasi dilakukan untuk memastikan bahwa proses tersebut dilakukan dengan cara yang lebih baik daripada di akhir setiap evaluasi, modifikasi, jika perlu, dibuat untuk implementasi selanjutnya.

\section{HASIL DAN PEMBAHASAN}

Pra penelitian peneliti mengumpulkan data dan sumber yang diperlukan dalam menyusun materi yang dibutuhkan oleh media pembelajaran berbasis Audio. Adapun dalam tahapan ini data-data didapatkan melalui kajian pustaka, mendatangi lokasi yang berkaitan, dan sumber internet untuk beberapa data yang sulit didapatkan. Proses pengumpulan data dilakukan selama lebih kurang satu bulan.

Hasil dari tahapan metode ADDIE yang telah dilakukan peneliti yan berupa tahapan analisis, desain, pengembangan, implementasi dan evaluasi. Penilaian kevalidan media audio berbasis podcast akan layak digunakan untuk uji coba apabila dengan skor rata-rata valid. Berikut hasil data validasi pada tabel 5.1.

Tabel 5.1. Rekapitulasi Validasi 3 Ahli

\begin{tabular}{|l|l|l|l|l|l|l|}
\hline $\begin{array}{l}\text { Produk Pengem- } \\
\text { bangan }\end{array}$ & $\begin{array}{l}\text { Validasi } \\
\text { Materi }\end{array}$ & $\begin{array}{l}\text { Validasi } \\
\text { Bahasa }\end{array}$ & $\begin{array}{l}\text { Validasi } \\
\text { Media }\end{array}$ & $\begin{array}{l}\text { Rerata } \\
\text { Skor } \\
\text { Perolehan }\end{array}$ & Kriteria & Kesimpulan \\
\hline $\begin{array}{l}\text { Media Audio } \\
\text { Berbasis Podcast }\end{array}$ & 4,78 & 4,38 & 4 & 4,38 & Sangat Valid & $\begin{array}{l}\text { Kriteria yang sangat valid sehingga dapat } \\
\text { diuji cobakan }\end{array}$ \\
\hline
\end{tabular}


HISTORIA: Jurnal Pendidik dan Peneliti Sejarah, 3(1), 49-56. DOI: https://doi.org/10.17509/historia.v3i1.21017.

Berdasarkan tabel 5.1 dapat diketahui kevalidan secara keseluruhan sebelum dilakukan uji coba peneliti melakukan validasi, yaitu validasi materi, validasi media, dan validasi bahasa dengan para ahli. Materi divalidasi oleh Dra. Retno Purwanti, M.Mus dengan hasil 4,78 yang berarti sangat valid, bahasa divalidasi oleh ahli bahasa dengan hasil 4,38 yang berarti sangat valid dan media dengan hasil 4 yang telah divalidasi Yenni Lidyawati, M.Pd dengan kesimpulan bahwa media audio berbasis podcast sangat valid.

\section{Deskripsi Tingkat kepemahaman dan keaktifan Mahasiswa terhadap Proses Pembelajaran}

Pretest dilakukan pada saat awal sebelum dilakukan pembelajaran dan uji coba yang merupakan langkah untuk mengukur kemampuan awal mahasiswa dalam mengetahui informasi mengenai Sriwijaya, sedangkan Postest dilakukan untuk mengukur tingkat pemahaman terhadap materi Sriwijaya mahasiswa semester 1 Program Studi Pendidikan Sejarah Universitas Sriwijaya dengan jumlah 28 orang setelah dilakukannya uji coba media Audio berbasis Podcast. Hasil Pretest dan Postest yang dilakukan oleh peneliti dapat dilihat pada tabel 5 . 2 berikut.

Tabel 5.2. Rekapitulasi Nilai Pretest dan Posttest

\begin{tabular}{|l|l|l|l|l|}
\hline \multicolumn{6}{|l|}{ Perolehan Nilai } \\
\hline & Pretest & Kategori & Posttest & Kategori \\
\hline $\begin{array}{l}\text { Rata-rata } \\
\text { Nilai 28 Mahasiswa }\end{array}$ & 36.42 & $\begin{array}{l}\text { E } \\
\text { (Buruk) }\end{array}$ & 82,32 & $\begin{array}{l}\text { B } \\
\text { (Baik) }\end{array}$ \\
\hline
\end{tabular}

Sumber: Pengolahan Peneliti, 2019

Berdasarkan tabel 5.2 yang menunjukkan nilai ratarata yang telah dicapai oleh peserta didik pada saat tes awal (Pretest), yaitu 36, 42 dengan kategori buruk, pada hasil tes akhir (posttest) peserta didik pada uji coba lapangan dengan menggunakan media Audio berbasis podcast dengan materi Sriwijaya mendapatkan nilai rata-rata sebesar 82,32 yang mengalami peningkatan sebesar 45,9\% termasuk kategori baik.

Berdasarkan hasil data perhitungan $\mathrm{N}$-gain di atas berdasarkan hasil Pretest dan posttest didapat $\mathrm{N}$-gain dengan nilai 0,72 yang dapat disimpulkan jika indeks $\mathrm{N}$-gain $0,72 \geq 0,7$ maka indeks $\mathrm{N}$-gain termasuk kedalam kategori tinggi sehingga media Audio berbasis podcast memiliki pengaruh yang sangat tinggi terhadap pemahaman materi mahasiswa dan dapat dikatakan media audio berbasis podcast sudah layak untuk digunakan sebagai media pembelajaran sejarah.
Tabel 5.3. Rekapitulasi Presentase Nilai Keaktifan Mahasiswa

\begin{tabular}{|c|c|c|c|c|}
\hline \multicolumn{5}{|l|}{ Perolehan Nilai } \\
\hline Jumlah Mahasiswa & Indikator & $\begin{array}{l}\text { Jumlah } \\
\text { Nilai }\end{array}$ & $\begin{array}{l}\text { Rerata } \\
\text { Keakti- } \\
\text { fan } \\
\text { Mahasi- } \\
\text { wa }\end{array}$ & Kategori \\
\hline 28 Mahasiswa & 10 & $718.74 \%$ & $71.87 \%$ & Aktif \\
\hline
\end{tabular}

Sumber: Pengolahan Peneliti, 2019

Berdasarkan hasil tabel 5.3 dari rerata di atas dimana ada 10 indikator dengan 28 mahasiwa yang memiliki jumlah nilai dari 10 indikator $718.74 \%$ dan menghasilkan nilai rerata $71.87 \%$ yang berarti mahasiswa aktif ketika peneliti melakukan uji coba, dengan hal tersebut mahasiswa merespon dan emmahami media yang di ujicobakan.

\section{Deskripsi Kemenarikan Media Audio berbasis Podcast}

Proses ini, peneliti melakukan validasi produk aplikasi kepada ahli yang memahami mengenai perncangan dan pengembangan media Audio berbasis Podcast untuk pembelajaran, proses ini dilakukan selama lebih kurang satu minggu.

Tabel 5.4. Daftar Perbaikan dan Masukan Experts

\begin{tabular}{|c|c|c|}
\hline No. & Validator & Revisi \\
\hline 1 & Validator Ahli Materi & $\begin{array}{l}\text { 1) Perlu ditambahkan } \\
\text { dengan data primer } \\
\text { untuk memperkuat } \\
\text { pernyataan tentang } \\
\text { Sriwijaya. }\end{array}$ \\
\hline 2 & Validator Ahli Bahasa & 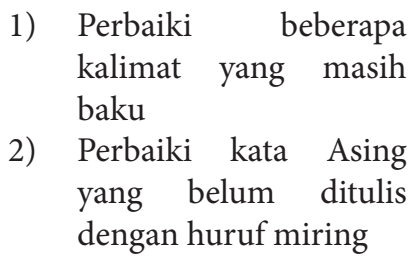 \\
\hline 3 & Vaidator Ahli Media & $\begin{array}{l}\text { 1) Sudah baik, namun } \\
\text { perlu adanya perbaikan } \\
\text { pada intonasi suara } \\
\text { 2) Suara yang dihasilkan } \\
\text { terlalu datar diperlukan } \\
\text { tinggi rendahnya suara } \\
\text { 3) Suara yang dihasilkan } \\
\text { terlalu cepat sehingga } \\
\text { perlu adanya perbaikan } \\
\text { lagi. }\end{array}$ \\
\hline
\end{tabular}

Sumber: Pengolahan Peneliti, 2019 
Data perbaikan dan masukan dari Experts pada tabel 5.4 menunjukan banyaknya perbaikan yang dilakukan dalam pengembangan media audio berbasis podcast. Peneliti melakukan perbaikan sesuai dengan seluruh masukan ahli untuk mendapatkan hasil produk yang valid. Hasil dari kemenarikan media dilakukan pada tahapan data lapangan diperoleh dari rekapitulasi skor respon menggunakan angket dapat dilihat pada tabel. 5.5. durasi 10:38 menit dan memiliki ukuran file 14, $3 \mathrm{MB}$ dengan materi yan mengarah ke Sejarah lokal Sumatera Selatan ,yaitu Kerajaan Sriwijaya.

Penggunaan audio berbasis podcast sendiri yaitu dengan cara disimpan di Handphone, di Laptop, kemudian bisa di upload di situs Website, maupun dapat disebarluaskan di media sosial lainnya. Cara cara efektif untuk penggunaanya lebih baik disimpan di Handphone sehingga mahasiswa dapat mendengarkannya dimana

Tabel 5.5. Rekepitulasi Kemenarikan Produk

\begin{tabular}{|l|l|l|l|l|l|}
\hline Aspek Penilaian & Uji perorangan & $\begin{array}{l}\text { Uji Kelompok } \\
\text { Kecil }\end{array}$ & $\begin{array}{l}\text { Rerata Skor } \\
\text { Perolehan }\end{array}$ & Kriteria & Kesimpulan \\
\hline $\begin{array}{l}\text { Kemanarikan } \\
\text { Produk }\end{array}$ & 38,2 & 61 & 49,6 & $\begin{array}{l}\text { Cukup } \\
\text { Menarik }\end{array}$ & $\begin{array}{l}\text { Memenuhi cukup menarik sehingga } \\
\text { produk layak digunakan }\end{array}$ \\
\hline
\end{tabular}

Sumber: Pengolahan Peneliti, 2019

Berdasarkan pada tabel 5.5 diketahui bahwa keseluruhan hasil analisis kemenarikan produk memperoleh presentase sebesar 49,6. Selanjutnya hasil dari presentase kemenarikan produk dapat ditafsirkan dan diputuskan bahwa produk media yang dikembangkan masuk kriteria cukup menarik untuk digunakan dalam pembelajaran.

Beberapa saran dan komentar dari uji kemenarikan dari One to One Learners dengan lima responden Mahasiswa Program Studi Pendidikan Sejarah Semester 1, yaitu (1) perbaikan intonasi suara, dan tinggi rendahnya suara sehingga pendengar mampu membedakan sub-sub (2) durasi yang terlalu panjang. (3) Media audio podcast jangan terlalu cepat untuk diputar dan waktunya juga jangan terlalu singkat jadi lebih mudah dipahami oleh mahasiswa (4) Secara format audio berbasis podcast sudah sangat bagus, terutama kejelasan materi, kejernihan suara, ukuran Audio mampu mengefisiensikan waktu.

Saran dan komentar dari Small Group, dengan 11 mahasiswa Semester 1 Program Studi Pendidikan Sejarah Universitas Sriwijaya untuk menjadi responden, yaitu (1) jeda yang terlalu lama (2) durasi media Audio Berbasis Podcast sudah cukup baik (3) menginginkan agar durasi media Podcast untuk lebih dipersingkat lagi.

\section{Produk Audio berbasis Podcast}

Produk akhir dari proses pengembangan ini berupa media audio berbasis podcast untuk pembelajaran sejarah di mata kuliah Sejarah Indonesia Kuno pada mahasiswa pendidikan Sejarah semester 1. Media audio berbasis podcast ini merupakan media audio yang dihasilkan melalui proses perekaman di studio rekaman untuk menghasilkan audio yang jernih, dengan ukuran pun dan kapan pun, untuk lebih baiknya lagi bisa menggunakan Earphone sehingga suara sangat jelas.

Media audio berbasis podcast dapat digunakan berulang-ulang dimana pun baik dirumah, maupun di tempat yang diinginkan dan waktu yang diingikan sehingga mahasiwa dapat memahami materi lebih baik lagi, bahwa terjadinya pengulangan dalam mendengarkan materi melalui audio dapat melatih daya hapal dan ingatan Mahasiswa sehingga materi yang disampaikan oleh audio dapat dipahami dengan sangat baik.

Gambar 1.1. Contoh Tampilan audio berbasis podcast di Laptop

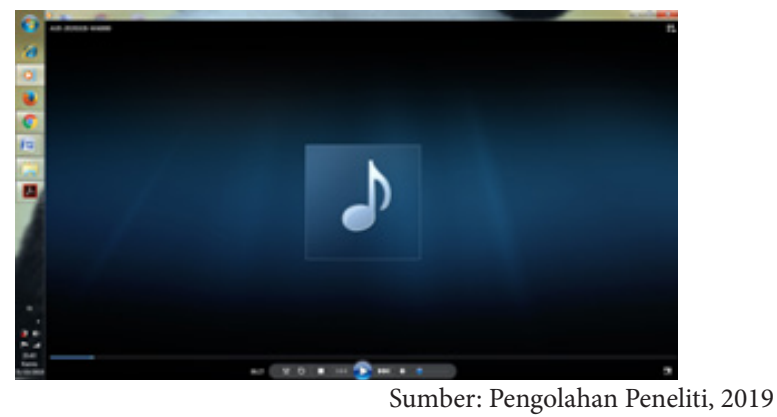

Secara keseluruhan, media audio berbasis podcast ini layak dan efektif digunakan dalam proses pembelajaran. Hal ini dapat dilihat berdasarkan evaluasi yang dilakukan oleh beberapa ahli yaitu ahli materi 4,78, ahli bahasa 4,38 dan ahli media 4 dengan perolehan rerata 4,38 yang termasuk kategori sangat valid untuk dilakukan pada tahap selanjutnya. Media juga diuji cobakan pada kelompok perorangan dan kelompok kecil, serta ujicoba

HISTORIA: Jurnal Pendidik dan Peneliti Sejarah, p-issn:2620-4789 | e-issn:2615-7993 
HISTORIA: Jurnal Pendidik dan Peneliti Sejarah, 3(1), 49-56. DOI: https://doi.org/10.17509/historia.v3i1.21017.

Gambar 1.2 Contoh Tampilan audio berbasis podcast di
Handphone

lapangan dengan nilai Pretest dan Postest, kemudian nilai keaktifan yang dinilai oleh observer.

Uji coba perorangan dilakukan oleh lima orang dan uji coba kelompok kecil dilakukan oleh 11 orang. Kegiatan uji coba perorangan dan uji coba kelompok kecil dilakukan untuk mengetahui keterterapan media. Perolehan presentase uji coba perorangan dengan hasil 38,2 dengan kategori kurang baik. Uji coba kelompok kecil memiliki hasil 61 yang masuk kategori baik sehingga mengasilkan rerata 49,6 yang berarti cukup baik atau cukup menarik.

Subjek uji coba dilakukan di Mata Kuliah Sejarah Indonesia Kuno 1 Mahasiswa Pendidikan Sejarah Universitas Sriwijaya dengan jumlah 28 orang. Sebelum melakukan penerapan Implementasi atau pun Fieldtest peneliti terlebih dahulu memberikan tes berupa soal Pretest yang memiliki hasil rerata 36,42 dengan kategori buruk, saat proses berlangsung akan ada observer yang menilai keaktifan mahasiswa dengan hasil rerata 71,87 dengan kategori aktif, selanjutnya peneliti akan melihat hasil akhir dengan memberikan Postest dengan hasil rerata 82,32 dengan kategori baik.

Berdasarkan hasil data perhitungan Pretest dan Postest, peneliti akan menguji normalitas dengan menggunakan rumus $\mathrm{N}$-gain dengan hasil Pretest dan Posttest didapat $N$-gain dengan nilai 0,72 yang dapat disimpulkan jika indeks $\mathrm{N}$-gain $0,72 \geq 0,7$ maka indeks $\mathrm{N}$-gain termasuk kedalam kategori tinggi sehingga media Audio berbasis Podcast memiliki pengaruh yang sangat tinggi terhadap pemahaman materi mahasiswa dan dapat dikatakan media audio berbasis podcast sudah layak untuk digunakan sebagai media pembelajaran sejarah.

Hal ini menunjukkan bahwa media audio berbasis podcast sangat valid, efektif, menarik untuk digunakan dalam pembelajaran sejarah pada Mata Kuliah Sejarah
Indonesia Kuno Mahasiswa Pendidikan Sejarah Universitas Sriwijaya.

\section{SIMPULAN}

Berdasarkan analisis temuan yang dipaparkan di atas dapat ditarik kesimpulan bahwa kelebihan media audio berbasis podcast yang telah dikembangkan menjadi media pembelajaran sejarah yang dapat digunakan pada saat pembelajaran sejarah terutama bagi mahasiswa Pendidikan Sejarah Universitas Sriwijaya dengan memberikan kemudahan dalam belajar, terutama media audio berbasis podcast yang bisa digunakan kapan pun dan dimana pun oleh Mahasiwa, dengan melakukan pengulangan dalam mendengarkan media audio, dibagikan di media Sosial manapun termasuk aplikasi chatting berupa Whats App, serta dapat diupload pada situs website.

Kekurangan dari media media audio berbasis podcast yaitu (1) hanya mengandalkan suara (2) mahasiwa sedikit akan menjadi bosan jika hanya mendengarkan suara dan tidak ditambahi dengan sedikit musik (3) media audio berbasis podcast sebaiknya tidak digunakan untuk materi yang terlalu panjang.

Berdasarkan validasi ahli peneliti memberikan saran berupa (1) sebaiknya media audio berbasis podcast tidak digunakan untuk materi yang panjang (2) media audio berbasis podcast tidak selalu digunakan hanya berdasrkan materi tertentu saja (3) dilakukanya pelatihan bagi pendidik dalam membuat media audio berbasis podcast karena dalam proses pembuatannya sangat mudah.

Media audio berbasisi podcast merupakan media yang telah layak untuk diuji cobakan kelapangan maupun disebarluaskan kepada tenaga pendidik dengan hasil validasi tiga ahli yang telah dilalui, yaitu Validasi bahasa dengan hasil skor 4,78, Validasi Bahasa dengan hasil 4.38, Validasi media hasil Validasi dengan nilai 4 berarti media Audio Podcast layak untuk diuji cobakan.

Berdasarkan dari data perhitungan $\mathrm{N}$-gain yang telah dihasilkan berdasarkan hasil Pretest dan posttest didapat $\mathrm{N}$-gain dengan nilai 0,72 yang dapat disimpulkan jika indeks $\mathrm{N}$-gain $0,72 \geq 0,7$ maka indeks $\mathrm{N}$-gain termasuk kedalam kategori tinggi sehingga media audio berbasis podcast memiliki pengaruh yang sangat tinggi terhadap pemahaman materi mahasiswa. Terlebih lagi beberapa respon dan saran mahasiswa yang mengatakan media audio berbasis podcast mudah dan sangat membantu, dapat disimpulkan bahwa media audio yang telah dibuat sangat efektif. 


\section{REFERENSI}

Arkün, S., \& Akkoyunlu, B. (2008). A Study on the development process of a multimedia learning environment according to the ADDIE model and students' opinions of the multimedia learning environment. Interactive educational multimedia: IEM, 17, 1-19. https://www.raco.cat/index.php/ IEM/article/view/205357/273895

Branch, R.M. (2009). Instructional design: the ADDIE aproach. USA:Springer.

Fadilah, E., Yudhapramesti, P., \& Aristi, N. (2017). Podcast sebagai Alternatif Distribus Konten Audio. Kajian Jurnalisme, 1(1). http://jurnal.unpad.ac.id/ kajianjurnalisme/article/view/10562/6395.

Meryansumayeka, Moh. Yusuf dan Amalia. V. (2018). Pengembangan video pembelajaran berbasis pmri untuk mendukung mental calculation siswa dalam permasalahan aritmatika sosial. https:// www.researchgate.net/prfile/Meryansumayeka_ Meryansumayek/publication/326692453.
Mustika, R. (2016). Media pembelajaran sistem audio untuk pemberdayaan pendidikan di komunitas masyarakat. Masyarakat Telematika dan Informasi: Jurnal Penelitian Teknologi Informasi dan Komunikasi, 6(1), 57-68. https://mti.kominfo.go.id/ index.php/mti/article/view/75/63

Ratminingsih, N.M. (2016). Efektivitas media audio pembelajaran bahasa Inggris berbasis lagu kreasi di kelas lima sekolah dasar. JPI (Jurnal Pendidikan Indonesia), 5(1), 27-38. http://dx.doi.org/10.23887/ jpi-undiksha.v5i1.8292

Susanto, Ahmad. (2013). Teori belajar dan pembelajaran di sekolah dasar. Jakarta: Kencana Prenada Media Group.

Wicaksono, A. (2017). Media audio dalam meningkatkan kualitas proses pembelajaran apresiasi cerita pendek. Jurnal Shahih, 2(1), 67-78. 10.22515/shahih. v2i1.670. 